\title{
Thoughts on the linguistic history of Curaçao: how Papiamentu got the better of Dutch
}

\author{
Bart JACOBS
}

Leiden Centre for Linguistics ${ }^{(1)}$

\section{Introduction}

Papiamentu emerged on Curaçao in the second half of the $17^{\text {th }}$ century, i.e. shortly after the Dutch West India Company (WIC) had taken control of the island (1634). Dutch and Papiamentu have been in contact ever since, This puts Papiamentu in a rather unique position: no other Romance-based creole has shared most of its history with a Germanic prestige language, (2) In this period, Papiamentu and Dutch have developed a symbiotic relationship to the extent that the history of Papiamentu cannot be told let alone properly understood without reference to Dutch.

The continuous contact with Dutch has left predictable traces in Papiamentu: up to $30 \%$ of the vocabulary is of Dutch origin (see Wood 1970). However, an important and hitherto insufficiently addressed historical and socio-linguistic question is why Dutch itself did not creolize on Curaçao or otherwise become the principal language of the island's society at large. After all, Dutch was the principal European language on the island from the 1630 s to present, and its presence there predates that of Papiamentu (from the 1650 s onwards). Most colonial languages in the Caribbean have had a vast, long lasting linguistic impact in their respective colonies, either 'producing' creoles (e.g. English on Jamaica or French on Haiti) or otherwise becoming the main vehicle of communication (e.g. Spanish on Cuba). Not, though, on Curaçao. On this island, the language of all social classes and ethnicities is Papiamentu, a creole with an originally and still predominantly Iberian lexical base. The present article addresses the question why the colonial language, Dutch, was not appropriated by the population of Curaçao and how, instead, Papiamentu could emerge, spread and be consolidated on the
island.

(1) The author wishes to thank Gerald Stell for valuable feedback on an earlier draft of this paper. All disclaimers apply.

(2) In the Philippines, the Spanish-based creole Chabacano is in contact with English, and varieties of French-based Haitian Creole are in contact with varieties of English in the Haitian Diaspora. These contacts, however, are of a comparatively reduced time-depth and intensity. Perhaps only the history of the French-based creole of St. Lucia is comparable to that of Papiamentai from the mid-18th century onwards, its main superstrate language has
been English (Carreit 2000 ) 
In the literature, several socio-historical factors have been put forward which satisfactorily account for the comparatively small linguistic impact of the Dutch language in the former Dutch colonial empire at large. However, as we will see, not all of these factors seem to have applied to the specific case of Curaçao. Also, Dutch-based creoles did of course emerge in the Caribbean (Negerhollands, Skepi, and Berbice) and a restructured form of Dutch was at the source of Afrikaans in South Africa. It is therefore not immediately clear why we don't find a restructured form of Dutch on Curaçao or, put differently, how an Iberian-based creole was able to spread among Dutch colonists. This article discusses which factors were most decisive in shaping this linguistic state of affairs ( $\$ 3)$. I will zoom in on both macrofactors - i.e. factors that are said to have applied to the Dutch colonial empire at large and microfactors - i.e. factors which I think were Curaçao-specific. To set the stage for the discussion in $\S 3$, I will first sketch the history of the Dutch language on Curaçao and of its relation to Papiamentu from the mid-17 century up to present, dividing this history into four main stages.

\section{The history of Dutch on Curaçao in four stages}

The Dutch West India Company (WIC) took Curaçao in 1634, putting the island under the administration of the WIC's Chamber of Amsterdam. Dutch never ceased to be spoken on the island and is still a vital language there with just under $10 \%$ of the population speaking the language on a daily basis (see Table 1). This article is less concerned with the islands of Aruba and Bonaire, the other two Papiamentu-speaking islands. Since Papiamentu emerged on Curaçao (and from there diffused to the other islands), I logically assume that the reasons for the success of Papiamentu are to be found here.

This article furthermore starts with the assumption that Papiamentu is genetically related to Cape Verdean Creole and that the precursor of Papiamentu, an early variety of Cape Verdean Creole, was transferred from Upper Guinea to Curaçao in the period between 1650 and 1675 (see Jacobs : 2012a, Chapter 7). This assumption will be of some importance in the discussion in $\$ 3$

Regardless of the ties with Cape Verdean, there is wide agreement among scholars that Papiamentu emerged on Curaçao in the second half of the $17^{\text {th }}$ century. Thus, for some three and a half centuries now, Curaçao has been the stage of Papiamentu-Dutch language contact. Below, I will propose to subdivide the history of this contact into four main stages. ${ }^{(3)}$ Most attention will be paid to the first period, which is where the clues lie hidden in terms of why Papiamentu, and not some (restructured) variety of Dutch, emerged on Curaçao.

(3) Hartog (1968) and Buddingh (1994) are comprehensive accounts of the history of Curaçao from 1634 to present; Rupert 2012 deal sipeeilically with the island's history up to the turn of the $19^{\text {th }}$ entury.

\subsection{Mid-1 $7^{\text {th }}$ century - Early $19^{\text {th }}$ century}

As noted, Papiamentu emerged on Curaçao in the latter half of the $17^{\text {th }}$ century. Already in the second half of the $18^{\text {th }}$ century, the language had become the principal communication vehicle among Afro-Curaçaoans. This latter assumption is supported by several testimonies. In 1704, for instance, the German Father Alexius Schabel mentioned in his travel account that the 'slaves of Curaçao speak broken Spanish' (cf. e.g. van Wijk: 1958, 169 and Bartens: 1996, p. 248). A few decades later, in 1732, a Father Caysedo reported that, in addition to Spanish, Portuguese, and Dutch, the people of Curaçao spoke 'el idioma del país' ['the language of the countryl' (in Hartog : 1968, p. 157). A legal deposition of 1737 mentions the use of the 'creolse taal' ['creole language'] by Afro-Curaçaoans (Rupert: 2012, p. 214), Last but not least, the first explicit mention of the glossonym Papiamentu (and variants thereof) is found in a most interesting document dated 1747 relating to a court hearing. The document is discussed in detail in van der Velden (2006), Kramer (2008), and Jacobs \& van der Wal (to appear). Suffice it to note here that the document reveals that Papiamentu was the primary language spoken among the crew of a ship sailing under the Dutch flag that had just left Curaçao.

In the course of the 18th century, Papiamentu gradually diffused among the white European upper class which consisted mainly (but not uniquely) of Dutch Protestants and Sephardic Jews. This is evidenced by two of the earliest written attestations of Papiamentu, dated 1775 and 1783. It concerns letters composed by a Sephardic Jew to his mistress (see e.g. Salomons 1982 for discussion) and by a Dutch female citizen of Willemstad to her Dutch husband (see Jacobs \& van der Wal : to appear) respectively. ${ }^{(4)}$

It is interesting to note that Papiamentu first spread among European women and somewhat later among the men. This was observed, for instance, by Bosch $(1829$, p. 212): 'op Curaçao (...) is een Spaansch patois, papiemento genaamd, de taal, die de Negers en gekleurden, die de kinderen der blanke inwoners en een groot gedeelte van het schoone geslacht bij voorkeu onder elkander groot, gedeete van het schoone geslacht bij voorkeu onder elkander spreken'. With particular respect to Curaçao and Jamaica, Rupert (2012, p. 235) gives a plausible explanation for this state of affairs: "European women who lived in the colonies frequently picked up creole languages faster than the men, at least in part owing to their close association with domestic servants and their children's contact with slave children and
nannies."

In addition to Papiamentu and Dutch, the linguistic landscape in the $18^{\text {th }}$ century was complemented by Spanish, Portuguese, some English and French, a wide variety of African languages, possibly some Amerindian languages, and a secret language called Guene. As for Spanish, although the Spaniards had left Curaçao after it was taken by the Dutch in 1634 , the the Spaniards nonetheless very present on the island as the language of trade and religion. Also, although we lack numbers, Spanish was probably spoken natively by

(4) The 1783 letter was discovered only recently by the Letters as Loot project carried on the nature of the letter and its implications for Papiament ster Wal (to appear) report 
more than just a few Sephardic Jews. Portuguese was spoken by (a similarly unknown number of) Sephardic families up to the late $18^{\text {th }}$ century ${ }^{(5)}$

At the height of slavery, the number of different African languages spoken on Curaçao must have been considerable. However, the rate at which Africans shifted to Papiamentu upon arrival must have been impressive. There are no reports of Africans passing on their heritage language to subsequent generations on Curaçao. Thus, we must naturally assume that African languages disappeared from Curaçao as soon as new slaves ceased to be imported (i.e. towards the end of the $18^{\text {th }}$ century). As far as Amerindian languages are concerned, documentation is again scarce. The Papiamentu lexicon is endowed with several Amerindian words (see van Buurt \& Joubert : 1997), but it is possible that many of these entered the language through regional Caribbean Spanish. And many of the Amerindians that remained on Curaçao and Aruba after the Dutch conquest may well have spoken Spanish rather than an indigenous language (see Grant : 2008);

Findily, a type of secret or ritual language known as Guene, now extinct, was allegedly spoken, in addition to Papiamentu, by pockets of Afro-Curaçaoan land slaves (see Martinus [1996, Chapter 10] and the references therein). The slaves' use of a secret language alongside Papiamentu in this early period is striking in that it suggests that Papiamentu was understood early on by the majority of Dutch and Sephardic slave owners.

Arguably, the most productive scenario of Dutch-Papiamentu bilingualism in this early period emerged from the contact between Afro-Curaçaoan yayas (nannies) and children of Dutch slave owners. But the influence of Dutch on Curaçao stretched well beyond the typical master-slave relationships, as Rupert (2012, p. 231) outlines:

Dutch was the official language of government administration and trade, as well as the native language of the upper strata. All business of the West India Company and Curaçao's political and judicial administration was conducted exclusively in Dutch. Rising merchants of all backgrounds and ethnicities needed to be fluent in Dutch, with translators provided as needed, and duly noted in the margins of official documents.

On the other hand, the role of Dutch in evangelical domains in this period was minimal: the Christianization of the Afro-Curaçaoans was largely (and deliberately) left in the hands of Spanish/Venezuelan missionaries. This would however change in the early $19^{\text {th }}$ century.

\subsection{Early $19^{\text {th }}$ century - Early $20^{\text {th }}$ century}

A variety of circumstances, such as the slave revolts from 1795-1800 (Klooster \& Oostindie : 2011), caused the Dutch upper class and WIC officials to rethink their relationship with the increasingly influential Afro-Curaçaoan part of the population. One $19^{\text {th }}$-century measurement was to increase the

(5) In the $19^{\text {th }}$ century small pockets of immigrants from Madeira briefly reintroduced Portuguese on the island but, as far as I can tell, had no impact on Papiamentu. number of Dutch clergymen on Curaçao in an attempt to gain more control over the Christianization of slaves and freemen, which, as noted, previously first Dutch priest Jated almost exclusively by Spanish missionaries. The first Dutch priest, Johannes Niewindt, arrived in 1824 (Fouse : 2002, pp. 127-131 discusses him in detail). Strikingly, he chose to hold his sermons in Papiamentu, setting the example for all subsequent Dutch clerical activity on the island. As printing press was introduced in the 1820s (Rupert : 2012, p. 246), the following decades saw Dutch clergymen (Catholic as well as Protestant) produce a significant corpus of evangelical texts all of which were written in Papiamentu (e.g. Niewindt : 1833; Conradi : 1844; van Dissel 1865). In 1916, Eybers edited the first translation into Papiamentu of the entire Bible.

Parallel to the increased evangelical efforts, attempts were made to implement a sound educational system and promote the Dutch language on (Fouse : 2002, p. 137). Already the officiation Director van Paddenburgh Dutch : 2002, p. 137). Already the official language of the government, Dutch was declared the official language of school instruction by law in 1819 , but it would still take some time for a full-fledged educational system to develop (Fouse : 2002, p. 137). In 1849, Father Jacobus Putman wrote a dactic grammar of Dutch in Papiamentu. (6)

These developments in the religious and educational domains were an important incentive for new Dutch words and features to enter the Papiamentu language. For instance, the passive auxiliary $\mathrm{Pap}$ wordu ( $<\mathrm{Du}$ worden) completely absent in Papiamentu texts from the late- $18^{\text {th }}$ and early-19) centuries, was first introduced in evangelical texts from the latter half of the $19^{\text {th }}$ century (cf. Sanchez : 2005; Jacobs : 2011). (7) Pap wòrdu is nowadays solidly integrated in the Papiamentu grammar (see Eckkrammer : 2004).

Yet, in spite of the increased presence of Dutch, the advance of Papiamentu as the language of the society at large continued. Cohen Henriquez (1934) affirms that in the course of the $19^{\text {th }}$ century Papiamentu had already become widespread in Otrobanda, the predominantly Dutch Protestant neighbourhood
of Willemstad.

\subsection{Early $20^{\text {th }}$ century - 1969}

A third phase of Dutch influence on Curaçao was prompted by the establishment of an oil refinery of the Royal Dutch Shell on Curaçao in 1915, encouraging waves of immigration from the Netherlands as well as remodelling of the Curaçaoan school system with Dutch as the sole well as of instruction. As noted by Fouse $\left(2002\right.$, p. 146), still in the first half of $20^{\text {th }}$ century, "certified teachers began arriving from the Netherlands to teach in the primary schools (...)". The Dutch linguistic educational policy was one of complete submersion and "students were punished if caught speaking in

(6) Putman (1849) is accessible under

http://archive.org/details/proeveeenerhollo0unkngoog

(7) Bakhuis (2012) deals extensively with Dutch

texts from 1833-1875. deats extensively with Dutch loanwords in evangelical Papiamentu 
Papiamentu at school" (Fouse : 2002, p. 147). Fouse (2002, pp. 147-150 sketches how, instigated by the foundation of the Shell refinery, anti-Dutch 列

$20^{\text {th }}$ century, culminating in the famous 1969 labour rebellion.

\subsection{9 to present}

Against this background, the second half of the $20^{\text {th }}$ century has seen in marker and a symbol of Dutch Papiamentu grow in its role as an identity marker and a symed and Antillean culture; the Papiamentu literary output has of the language in the Kester \& Fun $(2012$, p. 243) report that on Curaçao in the las school system. Kester \& Fun (2012, p. 243 ) (instead of Dutch) has increased two decades or so, "the use of Papiamentu (instead system."

in all formal domains, including the school system."

Of the languages spoken on Curaçao in the $17^{\text {th }}$ and $18^{\text {th }}$ centuries (cf. \$2.1), African languages, Amerindian languages, Guene, and Portuguese are no longer heard on any of the $\mathrm{ABC}$ islands. Only Papiamentu, Dutch and Spanish have persisted and in the course of the $20^{\text {th }}$ century Eng Spanish have peringly important, especially on Aruba (see Table 1). While the become increasingly important, especially on the ABC islands at present is number of true Papiamentu-Dutch bilinguals on the ABC difficult to quantify even by approximation, a comparison of cen has slightly the 1980s and 2000s (Table 1) suggests that the use increased at the cost of Papiamentu in recent decades.

\begin{tabular}{|l|l|l|l|l|}
\hline & Aruba, 1981 & Aruba, 2000 & Curaçao, 1981 & Curaçao, 2001 \\
\hline Papiamento & 80.1 & 69.4 & 86.9 & 80.3 \\
\hline Dutch & 5.0 & 6.1 & 6.8 & 9.3 \\
\hline English & 10.6 & 8.1 & 3.3 & 3.5 \\
\hline Spanish & $?$ & 13.2 & $?$ & 4.6 \\
\hline
\end{tabular}

1. Census of 1981 and 2000/01 (adapted from Maurer : 1998,p. 143 and Kester \& Fun : 2012, p. 238)

be more precise about the position of Dutch on Curaçao at present, (hat it is "barred from Dijkhoff, Kouwenberg \& Fat (2004, p. 2107). nor 'national', and in the arts, social manifestations that may be termed "local or "national , and in the other the non-print media and local politics, its role is negligible." On the other the non-print hand, Dutch has been able to consolith there have been calls for introducing of education and politics. Although there have calls have not been rewarded, Papiamentu at all levels of education, these calls have not been is still considlargely due to the fact that the economic importance of Dutch is still considlargely "providing access to advance erable: "proficiency in Dutch is still (Kouwenberg \& Fat : 2004, p. 2107). As study and better job opportunities" (Kouwenberg \& Fat : a result, schools where Papiamentu is the only language of instruction have a result sche predict in the late $20^{\text {th }}$ century. not gained the popularity some might have predicts its comparatively low socio-

The double status of Dutch on Curaçao (that is, its comparating cultural prestige vs, its high economic importance) and the corresponding language-political and educational issues are what Oostindie (1995) refers to as 'Curaçao's dilemma': whilst Papiamentu is increasingly propagated as the symbol of the culture of the ABC islands, the corresponding desire to introduce Papiamentu in the political and educational realm at the cost of Dutch is not (yet) a real option.

According to Oostindie (2008, p. 8), "in the Antilles Dutch is an unpopular second language only". Based on several (informal) personal conversations with native speakers, I would argue that the social status of Dutch on Curaçao is not as deplorable as suggested here by Oostindie, although indeed Spanish, English and Papiamentu are generally more popular (viz. perceived as nicer, prettier, etc.) than Dutch. In any case, most Papiamentu-Dutch bilinguals have no qualms whatsoever to code-switch. Also, an important share of the local literature is still produced in Dutch (Dijkhoff, Kouwenberg \& Fat : 2004, p. 2107).

The Dutch language has been a pivotal presence on the $\mathrm{ABC}$ islands ever since the 1630s. Even though Dutch preceded Papiamentu on Curaçao, the former has never been able to seriously compete with the latter in the colloquial domains of society, or to 'produce' a creole. The question why Dutch (or a restructured variety thereof) failed to become the primary vehiclo of communication on Curaçao, an issue referred to by Kramer [2004, p. 136 ] as the 'Curaçao Paradox', is addressed next.

\section{The Curaçao Paradox}

Curaçao clearly differs from many if not most other (former) European Caribbean colonies, such as Jamaica, Haiti, or Cuba, where the colonia languages English, French and Spanish, or creolized forms thereof, have become the primary language of the respective societies. It is not immediately clear why Dutch failed to do the same on Curaçao. From both a demographic and a chronological perspective, the conditions appear to have been idea for Dutch to impose itself in either restructured or unrestructured form onto the local society. Not only were the Dutch the first to arrive in the $1630 \mathrm{~s}$, founding the subsequent colonial Curaçaoan society; they were also more numerous, had a stronger legal status, and owned more slaves, than any other European power throughout the history of Curaçao. ${ }^{(8)}$ Unfortunately, the first complete census is only from 1789 . It shows that at the time, $12.5 \%$ of the European population was Dutch, while $7.5 \%$ was Sephardic Jewish (Maurer : 1998 , p. 192). From the few pieces of demographic data available on earlier periods we can furthermore learn that the island counted around 320 Dutch Protestant families in 1713 as opposed to 140 Sephardic Jewish families (Maurer : 1998, p. 192) and that, in the 1740s, the Dutch owned $75 \%$ of the slaves whilst the Jews owned the remainder (Fouse : 2002, p. 118).

It has often been observed that the sum of the Dutch linguistic legacy, considering the vastness of its (former) colonial empire, is relatively minor

(8) The Sephardic Jews, the second largest European slave-keeping group, were, to the best of our knowledge, never in the possession of more than 25\% of the slaves (Maurer 1998, p. 199; of. Emmanuel \& Emmanuel : 1970, p. 227). 
in comparison to that of the other main European colonial powers. Holm (1988, p. 322) (1988, p. 322) succinctly summarizes: "It is remarkable that hich at its height in linguistic remnants of the vast empire of the Dutch, which at its height in the middle of the seventeenth century circled the paribbean, Brazil, Africa, India, Malaysia, Indonesia Taiwan, and Japan". In the literature, several major factors - I will Indonesia, Taiwan, and Japan'. In the literature canonically been identified discuss these under 'macrofactors' in $\$ 3.1$ - have canonically

as primary reasons for of the pale Dutch linguistic heritage.

However, while these macrofactors indeed plausiome parts of the Dutch failing diffusion of Dutch among the local people in some parts of the Dutch colonial empire, not all of them seem to have applied to the specific case of Curaçao. Therefore, in order to explain the emergence of Papiamentu a of Curaçao. Therefore, in order to these the cost of Dutch, several Curaçao-specific factors I will refl. These are as 'microfactors' - need to be taken into consideration as well. These are discussed in $\$ 3.2$.

\subsection{Macrofactors}

\section{A. 'The Dutch succeeded other colonizing powers'}

In many of their settlements on the African West Coast and in South Ine Portuguese, finding (a form of) East Asia, the Dutch ind wide-spread use (see van Goor [2004, Chapter Portuguese to be alr [1993, Chapter 2] with regards to the Dutch in Asia). In 3] and Groeneboer [1993, Chapter 2] with regards vein, the Dutch succeeded the English in Suriname and 'inherited' many of their slaves, who by that time already spoke (a precursor of) the many of their creole Sranan Tongo. The case of Curaçao was different English-based creole Sranan Tongo. The curacao already in 1499, but though. Of course, the Spanish had occupied Curaçao already in 1490, but it is well-known that these never actively colonized it; when the Dutch West Indian Company (WIC) took the island in 1634, a small garrison of Spanish Indian Company (WIC) took the island in 1634 , a voluntarily withdrew to the soldiers (without slaves) was encountered who voluntarily withdrew to the mainland. Less than a hundred Amerindians were allowed to remain on Curacao, but since these were not used as slaves or otherwise involved in any of the colonizer's activities other than cattle raising (Hartog: 1968, pp. 89, 90), we must assume they had little to no socio-linguistic impact in the early decades of colonization (cf. Martinus : 1996, p. 22 for similar thoughts). In decader words, there was no demographic, and thus no linguistic, continuity other words, there was the between the pre- and the post-1634 periods. Rather, with the arrival of the Dutch the demographic-linguistic history of Curaçao started from scratch (Kramer: 2004, p. 108) and, from a chronological perspective, there was (Kramer : 2004, p. 108) and, from a chronolanguage from spreading among nothing that should have prevented the Dutch language from spreapened.

\section{B. 'The Dutch did not remain long enough to have a linguistic impact'}

Indeed, in several holdings in West Africa and the East Indies the Dutch spell was simply too short for them to have any long-lasting linguistic impact $^{(9)}$. On Curaçao, however, as is well known (and disregarding a decade of English rule on Curaçao in the early $18^{\text {th }}$ century), the Dutch have been a continuous presence up until this very day.

\section{C. 'Dutch reluctance to educate and evangelize indigenous people'}

According to Postma (1990, p. 70), of all European colonial powers. "the Dutch may well have been the least interested in efforts to educate and Christianize the African population". This was to a large part due to negative attitudes towards non-whites (Postma : 1990, p. 71). This attitude had an obvious socio-linguistic correlate. Reinecke (1937, p. 443, cited in Holm : 1988 , p. 323) noted in this regard that "till the middle of the $19^{\text {ti }}$ century the Hollanders regarded their language as a sort of caste-language and heard unwillingly its employment by their inferiors". The linguistic attitude referred to here by Reinecke is historically well-documented, at least for the East Indies. Dutch officials in Batavia, for instance, explicitly expressed their concerns about the possible 'corruption' of Dutch in the mouths of the indigenous, fearing that Dutch would undergo a similar fate as the local variety of Portuguese, which, in becoming the local lingua fiama, had preserved only few structural correspondences with the European standard (see particularly Groeneboer: 1993, Chapter 2). In Batavia, for instance, such concerns made it more attractive to the Dutch colonizers to adopt and use the local variety of (restructured) Portuguese in communication with the indigenous people (cf. Maurer: 2011, p. 3).

A similar sociolinguistic attitude seems to have characterized the Dutch Protestant upper class of Curaçao. Although this attitude is not as clearly documented for the Dutch on Curaçao as it is for the Dutch in the East Indies, we do know that Curaçaoan slaves were not allowed to learn Dutch (van der Velden : 2006, p. 167, drawing on Waltmans : 2003). The fact that Dutch Protestants on Curaçao initially did not allow their slaves to become members of the Protestant church (Hartog : 1968, p. 148) can also be seen as symptomatic for such an attitude. In fact, in line with Oostindie (2008: pp. 8, 9), we may argue that the Dutch reluctance to evangelize the Afro-Curaçaoan community (cf. \$2.1) was indeed an important reason why the legacy of Dutch on Curaço is comparatively small. After all, it is common knowledge that particularly in the Spanish, Portuguese, and French colonies the Christianization of the population facilitated and accelerated the transfer of the colonial language. Also, as Oostindie (2008, p. 9) correctly points out, the much more noteworthy religious efforts of the Dutch in South

(9) Groeneboer (1993, p. 92) describes the disappearing of Dutch in Malacca and Ceylon: "Toen bijvoorbeeld Malaka, dat in 1795 door de Engelsen was ingenomen, uiteindelijk in 1818 aan Nederland werd teruggegeven, bleek het geheel te zijn verengelst (...). Hetzelfde geldt ook voor Ceylon waar na de komst van de Engelsen in 1796 het Nederlands zeer snel verdwenen was (...). Alleen in de Kaapkolonie (Zuid-Afrika) kon het Nederlands zich handhaven, ook nadat het in 1795 door de Engelsen was ingenomen en in 1814 officiee in Ingelae handen was overgegaan, dankzij de omvangrijke Nederlandse volksplantingen van de reventiende en de achttiende ceuw." 
Africa (compared to their other colonies) is likely an important reason why Africa (compared to their other colonis) in inder south the linguistic legacy of Dutch colonialism is indecd most significant in Souh Africa.

As previously outlined $(\$ 2.2)$, in the $19^{\text {th }}$ century the Dutch began to invest more in the schooling and evangelization of the Afro-Curaçaoan part invest more in the schoorte increasingly exposed to Dutch. However, by of society who, as a result, were increasingly explab established as the principal that time Papiamentu had already become firmly established adopted also by language of the lower and middle classes, and was being adopted alo by language of the low as many Dutch clergymen (cf. $\$ 2.2$ ). Fouse (2002, p. early as 1769 , "the Jesuit priest Rodier sent a letter to the Dutch Partiamentu". Reverend Kuiperi, for instance, already preached in Papiamentu four months after Kuiperi, for instance, al 1858 (Coomans : 2001, in the postscript to Kuiperi [1862], no page numbers).

D. 'The Dutch were linguistically more accommodating than other colonial powers'

Macrofactor D entails the claim that the Dutch were generally more Macrofactor D entails the clinguistically than the British, Spanish, and French (cf. Holm : 1988, p. 323).

It should be stressed that, if the Dutch were more accommodating linguisIt should be stressed powers, this was not due to some innate capacity tically than other colonial powers, this was not due to some in with the Dutch for second language acquisition, but more likely correlated with the colonizers' primary interest in trade as opposed to actual settlement and colonizers' primary interest in : 2007, p. 159).

列

Of course there could be ove likely to accommodate linguistically. come in second will generally be more likely to accommodat the British and However, while that might be the case, it should be noted that the British ane the French also often succeeded other European powers, yet they nation. And ty typically managed to impor apply to Curaçao, reversely, as mentioned previously, macrofictor speech here as well. So certainly, yet the Dutch ended up accommodating their speech here as well. Socertainly, there seems to be some truth to the claim that the Dutch were me chronology to accommodate than other colonial powers, in

of their settlement in a certain place or region.

The of (restructured) Portuguese by Dutch officials The use of local especially for and clergymen is historically remarkably the East Indies (see e.g. Groeneboer : 1993) and substantian Portuguese-based presence of several dozens of creoles such as Papia Kristang (Hancock: Tugu Creole (Maurer : 2011), all spoken in places which had the WIC, not under Dutch colonial rule. Curaçao was of course controlled by the We not under Dutch colonial Compagnie (VOC) who controlled the Dutch by the Verenigde Oostindische Compagnic (hore is some indirect historical evidence suggesting that WIC officials were us linguistically accommolating as their VOC colleagues.
This evidence concerns the Dutch WIC's history on the Petite Côte, a coastal area part of the historical Senegambia region in Upper Guinea. Here, the Dutch WIC was arguably the strongest commercial entity during a period of some five decades, from the 1620 s through to the late 1670 s, when the WIC lost its Petite Côte strongholds - Gorée, Rufisque, Portudal, and Joal - to France and was forced to withdraw from the region almost instantly. The trade in the Petite Côte region suffered considerably from the Dutch withdrawal and the subsequent French trading monopoly (Boulègue: 1989 , p. 97). At the same time, and more importantly in the present context, the linguistic landscape of the region changed drastically. During the Dutch commercial reign, a form of Portuguese (I assume an early variety of Cape Verdean Creole) had been the primary lingua franca in the area, and notably also in the afore-mentioned trading posts that were under Dutch rule. This can be inferred from a series of contemporary testimonies gathered by Ladhams (2006) regarding language use in the Petite Côte region. In several of these testimonies reference is made to the use of a 'corrupted' and or 'creole' Portuguese by the people in those villages in the $17^{\text {th }}$ century. Strikingly, along with the Dutch departure, references to the use of any form of Portuguese in the region disappear entirely in $18^{\text {th }}$-century testimonies (Ladhams : 2006, p. 89).

I believe the main reason for this was that, in that $18^{\text {th }}$ century, the French, in contrast to the Dutch, made serious efforts to preserve and diffuse their language in the region, for instance by employing so-called maitres de langue in negotiations with the local population (Parkvall : 1999, p. 194) or by sending children of mixed African-French descent to France and back in order to facilitate assimilation (Hargreaves : 1965, p. 179). As a result, segments of the local population began to identify with the French early on. Parkvall (1999) plausibly suggests that it is not unlikely that this identification process was accompanied by the acquisition of (some form of) French: "Regrettably, there is no evidence as to what language the Métis used among themselves, but since they often regarded themselves as Frenchmen (...), it would not seem unlikely if adoption, as far as possible, of French linguistic habits, was a feature of such an identification" (Parkvall : 1999, p. 194 , drawing on Knight : 1977). In the early $19^{\text {th }}$ century, the French in Senegal officially implemented their renowned assimilation policies; the first French-language school was founded in 1817 (Calvet : 2010, Chapter 1).

To briefly summarize, the Dutch, unlike their French successors, seem to have accommodated linguistically in the Petite Côte region, allowing the local variety of Portuguese to flourish in the region and perhaps even acquiring that variety themselves in order to conduct trade. It is important to add that of the WIC's five Chambers, it was the Chamber of Amsterdam which controlled both the Dutch holdings in the Petite Côte and the ABC Islands. Therefore, it seems reasonable to assume that socio-linguistic patterns of the Dutch in the Petite Cote applied also to the Dutch in $17^{\text {th }}$ - and $18^{\text {th }}$-century Curaçao. 


\subsection{Microfactors}

Thus, while macrofactors $\mathrm{A}$ and $\mathrm{B}$ did not apply in any way to the case of Curaçao, C and D, on the other hand, did. Yet, by themselves, C and D do not suffice to explain why a form of Dutch did not gain the upper hand on Curaçao. After all, these two factors were in effect also in the Virgin Islands, Dutch Guyana, and South Africa, yet in those places Dutch actually did have a major linguistic impact, witness the emergence there of Dutch-based creoles (Negerhollands, Skepi, and Berbice Dutch) and a very vital semi-creole (Afrikaans). Thus, in order to understand the Curaçao Paradox, we need to zoom in on microfactors, that is Curaçao-specific circumstances.

\section{a. Curaço's heterogeneous upper class and the role of the Sephardic Jews}

One such circumstance was the well-known fact that Curaçao's European upper class was not homogeneously Dutch, but consisted also of an influential Sephardic Jewish community (as well as of small pockets of other Europeans such as Frenchmen, Italians, Germans and Englishmen). The majority of the Curaçaoan Jews who settled on Curaçao in the 1650s must have spoken Portuguese and Spanish (see Joubert \& Perl : 2007).

In the first census, from 1789, Dutch Protestants constituted a $12.5 \%$ of the Curacaoan population; the Jews made up $7.5 \%$. This ratio of Dutch vs. Jews remained relatively stable in subsequent decades (Maurer : 1998, p. 192). (For details on the socio-economic position of the Jews vis-à-vis the Dutch throughout the $18^{\text {th }}$ and $19^{\text {th }}$ centuries, see Hoetink : 1958.) Drawing on Hoetink (1958), Mintz (1971) speculates about how the absence of a homogeneous upper class may have favoured the choice for Papiamentu as inter-group language (cf. Rupert : 2012, p. 234):

(...) in Curaçao, there were two upper stratum groups: the Portuguesespeaking Jewish colonists (...) and the Dutch-speaking Protestant colonists (...). Cultural interpenetration of these two groups was slight. Both groups learned and employed Papiamento, not only to communicate with their social subordinates, but also in order to communicate with each other. There is a strong socio-historical suggestion here that the presence of two 'master-groups' speaking mutually unintelligible languages, in contact with a subordinate group speaking a creole language, may well lead to the adoption of the creole by the master-groups as a common tongue. (Mintz: 1971, p. 493)

As pointed out by Parkvall (2003, p. 148), sharing the linguistic space with more than one high-status language typically seems to benefit the vitality of a creole. In addition to the case of Curaçao, Parkvall (2003, p. 148) mentions "the Seychelles and Vanuatu (in which both English and French are official) and the Kinubi communities of Kenya and Uganda (where English and Swahili can lay claim on being the languages of wider communication)" as cases in point. The creoles spoken in these areas (Seychellois, Bislama, and Kinubi respectively) are all in healthy condition compared to many other creoles world-wide (Parkvall : 2003, p, 145),
It is not clear exactly when the Sephardic Jews shifted to Papiamentu or at what rate, but we do know from a 1776 court document (presented e.g. in Maurer : 1998) in which a Sephardic Jew is cited as speaking Papiamentu and from the afore-mentioned 1775 Sephardic love letter that a (considerable) number of Jews was fluent in (and perhaps native speaker of) Papiamentu already in the latter half of the $18^{\text {th }}$ century. Thus, the role of the Sephardic Jews in the diffusion of Papiamentu was likely twofold: on the one hand, they encouraged the Dutch Protestants to accommodate linguistically; on the other hand, they shifted to Papiamentu themselves early on, passing it on to subsequent generations and contributing to its overall status.

\section{b. High rate of manumission and the lack of a plantation economy}

Another important Curaçao-specific factor that I argue favoured the diffusion of Papiamentu was the strikingly high rate of manumissions on Curaçao (see e.g. Hoetink : 1958 and more recently Jordaan : 2012), Quite early on the number of freed slaves on Curaçao easily exceeded the number of freed slaves in other Caribbean colonies (Klooster : 2009,p. 168). This was due mainly to the absence on Curaçao of large scale sugar plantations which characterized most other Caribbean colonies and which were dependent on slavery. On Curaçao, by contrast, we found a high number of private traders and small scale agricultural farms (Hoetink : 1958, p. 12; Klooster : 2009, p 169). Therefore, Klooster (2009, p. 169) notes, a slave on Curaçao was often considered a luxury item rather than an indispensible servant, a circumstance that "made him expendable in times of economic adversity" (Klooster : 2009,
p. 169). (10)

Recent research on Curaçaoan freed slaves by Jordaan (2012) shows that they formed an independent socio-economic group already by the early $18^{\text {th }}$ century. Assuming these freed slaves spoke Papiamentu as a first language, their increasing influence in the economy of Willemstad may well have been a considerable factor in the diffusion of Papiamentu among the Curaçaoan population at large.

As noted, the high rate of manumission was to an important extent due to the lack of a plantation economy and, as such, symptomatic of a society which was not hierarchically structured as straightforwardly as many other colonial societies at that time. I assume that in places where social divisions and hierarchies were drawn more transparently, such as in the typical plantation colonies across the Caribbean, the colonial language (or a restructured variety thereof) would have had (much) better chances of spreading among the lower classes.

(10) In 1789 freed slaves on Curaçao (14\%) already outnumbered Dutch Protestant (12.5\%) and Sephardie Jew (7.5\%) (Maurer : 1998, p. 192). Slightly different figure presented by Kloosier $(2009,0.168)$, in 1789 Curaçao counted 3,714 freed slaves, i.e, "17. percent of the population, a ligher pereentage than anywhere in the Caribbean". 


\section{c. High social prestige of Papiamentu}

The social vitality and prestige of Papiamentu at present is remarkably high compared to many other creoles (cf. Parkvall : 2003, p. 145). This is suggested also by Oostindie $(1995, \mathrm{p} .151)$ when he discusses why Sranan Tongo has played a lesser role in nation building in Suriname than Papiamentu has in Curaçao: "in tegenstelling tot het Papiamentu/o maar net als vrijwel alle andere creoolse talen, [behield] het Sranan altijd het stigma van vulgaire spreektaal voor de volksklasse". It is difficult to tell whether or to what extent (i) the particular socio-linguistic vitality of Papiamentu is due to the failure of Dutch to become a popular vehicle of communication on Curaçao or whether (ii) the vitality (and the corresponding emblematic value) of Papiamentu is somehow inherent to the language, irrespective of its position vis-à-vis Dutch. Parkvall (2003, p. 148) proposes that statement (i) applies, at least partially: "In the creole-speaking world, the weakest of the European colonial languages is Dutch (...) [I]t is likely that this is in part responsible for the high status of Papiamentu on Curaçao, Aruba and Bonaire". On the other hand, Parkvall (2003, p. 149) also recalls that in Suriname Sranan Tongo has not developed the socio-cultural importance Papiamentu has, in spite of the 'weakness' of Dutch. Therefore, while statement (i) may have applied, it can hardly be taken as the sole explanation for the high prestige of Papiamentu.

In fact, there are some clues suggesting that indeed the socio-linguistic vitality of Papiamentu is to an important extent inherent to it (statement (ii)). The afore-mentioned assumption that Papiamentu is an offshoot of an early variety of Cape Verdean Creole is again important here: upon arrival of native speakers of the latter on Curaçao in the second half of the $17^{\text {th }}$ century, and due to the heavy exposure to regional Spanish, this Portuguese-lexified creole was partially relexified towards Spanish, resulting in Papiamentu (see Jacobs : 2012c for further discussion). Now, it seems to me that the native Cape Verdean Creole speakers could just as easily have shifted to Spanish completely instead of initiating a relexification process. The very fact that they chose not to, I would argue, can be taken to suggest that the language in that early period already had a symbolic viz. emblematic function to its speakers; the (partial) relexification towards Spanish was a means for Capeverdeans to flag their acculturation whilst maintaining their own sociolinguistic identity.

One may legitimately ask why or how the language of this particular group of slaves (i.e. descendents of Capeverdeans) could diffuse so successfully on Curaçao. After all, they were but one small group amidst a rapidly growing and ethnically highly diverse Afro-Curaçaoan population. Clearly, these Capeverdeans must have had a considerable social prestige in order for them to have such a decisive linguistic impact on Curaçao. We may tentatively speculate about some of the reasons behind that prestige: First, speaking a language - an Afro-European creole - that was (at least to some extent) understood by both the African slaves and the European masters may very well have entailed a certain prestige (as pointed out by Parkvall [1999, p 205], though in a somewhat different context). Second, skin colour may have played a role; slaves from the already largely creolized societies of the Cape Verde Islands and Cacheu may, on average, have been lighter skinned than ethnically unmixed slaves from other parts of West Africa. Light skin colour, in turn, correlated positively with social standing on Curacao, especially in the first two centuries of Dutch settlement (see e.g. Hoetink : 1958 and Allen : 2007 on this topic). Third, many of the creole-speaking slaves may have already been baptized prior to their trans-Atlantic journey, which would have added to their prestige vis-à-vis non-Christianized slaves from other parts of West Africa.

\section{Final remarks}

This article addressed an urgent issue relating to the linguistic history of Curaçao, known as the Curaçao Paradox: how could an Afro-Iberian creole emerge, diffuse and consolidate itself on an island under Dutch colonial rule? Why didn't the colonial language gain the upper hand on Curaçao, in contrast to so many other Caribbean islands?

Section 2 sketched the history of the colonial and postcolonial relationship between Papiamentu and Dutch on Curacao. If we subdivide this history into four main periods, the first was doubtlessly most decisive in shaping the linguistic landscape: in a setting of great ethno-linguistic diversity, Papiamentu emerged first as the lingua franca and eventually as the native language of the society at large.

To shed light on the Curaçao Paradox, I distinguished between macrofactors (conditions that are thought to have held for all Dutch colonies) and microfactors (conditions specific to Curaçao). Not all macrofactors seem to have applied to the specific case of Curaçao. Thus, while the facts that the Dutch often succeeded other European nations or simply did not stay around long enough (macrofactors A and B) certainly help to explain the negligible Dutch linguistic heritage in many former colonies, they did not apply to Curaçao. On the other hand, the general reluctance among Dutch colonizers to educate and Christianize the indigenous or enslaved population (macrofactor C) did play a role also on Curacao, and so did the comparatively high Dutch readiness to accommodate linguistically (macrofactor D).

As the most significant Curaçao-specific microfactors I singled out, first, the heterogeneous Dutch-Sephardic character of the upper class and the early vernacularization of Papiamentu among the Sephardim (microfactor a); second, the comparatively high rate of manumission on Curaçao and the subsequently increasing socio-economic importance of Papiamentu-speaking freed slaves (microfactor $b$ ); third, the inherently high social prestige viz. emblematic value of Papiamentu and its Capeverdean precursor (microfactor c).

The story of Papiamentu is a turbulent but successful one. Some of the explanations for this success provided in the foregoing may have had more weight than others and future studies looking into the macro- and microfactors individually and with more detail are desirable, as the Curaçao Paradox eventually touches not only on the past, but also on the future of the people of the ABC-Islands. As Oostindie (1995, p. 152) aptly observes: "reflectie over het verleden kan helpen om het heden beter te begrijpen, en [kan] op die grond ook (...) helpen bij het nadenken over de toekomst van Curaçao en de Antillen." 


\section{Bibliography}

ALLEN (Rose Mary) : 2007, Di ki manera? A Social History of Afro-Curaçaoans, 1863-1917 (Utrecht: University of Utrecht).

BAKHUIS (Walter) : 2012, Nederlandse leenwoorden in het Curaçaose Papiamentu tussen 1833 en 1875: ontlening uit de Nederlandse spreektaal en haar spreektaalen dialectale varianten (Amsterdam : Vrije Universiteit Amsterdam).

BARTENS (Angela) : 1996, Die iberoromanisch-basierten Kreolsprachen (Frankfurt am Main : Peter Lang).

BOSCH (G.B.) : 1829, Reizen in West-Indië (Utrecht : Van der Monde).

BOULÈGUE (Jean) : 1989, Les Luso-Africains de Sénégambie (Lisbon : Instituto de Investigação Científica)

BUDDINGH (Bernard R.) : 1994, Van Punt en Snoa. Ontstaan en groei van Willemstad, Curaçao vanaf 1634 (Den Bosch : Aldus Uitgevers).

van BUURT (Gerard) and JOUBERT (Sidney) : 1997, Stemmen uit het verleden: Indiaanse woorden in het Papiamentu (Alphen aan den Rijn : Van Buurt).

van BUURT (Gerard) : 2001, "Afrikaanse woorden in het Papiamentu", Kristòf, 11 , 3 , pp. 1-24.

CALVET (Louis-Jean) : 2010, Histoire du Français en Afrique (Paris : Éditions Écriture).

COHEN HENRIQUEZ (Percy) : 1934, "De taal van Curaçao" Natuur en Mensch, 54, 4, pp. 31-34.

CONRADI (Cornelis) : 1844, Ewanhelie di SanMatheo (Curaçao : Fundashon pa Planifikashon di Idioma.

DIJKHOFF (Marta), KOUWENBERG (Silvia) and FAT (Paul Tjon Sie) : 2004, "The Dutch-speaking Caribbean", in AMMON (Ulrich), DITTMAR (Norbert), MATTHEIER (Klaus J.) and TRUDGILL (Peter), eds. Sociolinguistics. An international handbook of the science of language and society (Berlin/NewYork : Mouton De Gruyter), pp. 2105-2114.

van DISSEL (Sijbrand) : 1865, Evangeli segoen Marko (NewYork : American Bible Society).

ECKKRAMMER (Eva Martha) : 2004, "Passive voice in Papiamento: A corpusbased study on dialectal variability", in ESCURE (Geneviève) and SCHWEGLER (Armin), eds. Creoles, Contact, and Language Change: Linguistic and social implications (Amsterdam : Benjamins), pp. 209-219.

EMMANUEL (Isaac S.) and (EMMANUEL (Suzanne A.) : 1970, History of the Jews of the Netherlands Antilles (Cincinnati: American Jewish Archives).

EYBERS (G.J.) : 1916, E testament Nobo di nos Señor y Salbador Jesus Christo: Fielmente traduci segun e texto original (Amsterdam : Nederlands Bijbelgenootschap).

FOUSE (Gary C.) : 2002, The Story of Papiamentu. A Study in Slavery and Language (Lanham : University Press of America).

GARRETT (Paul) : 2000, "'High' Kwéyòl: The Emergence of a Formal Creole Register in St. Lucia”, in MCWHORTER (John), eds. Language Change and Language Contact in Pidgins and Creoles (Amsterdam : John Benjamins Publishing Company), pp. 63-101.

van GOOR (Jurrien) : 2004, Prelude to Colonialism. The Dutch in Asia (Hilversum : Uitgeverij Verloren). de GRANDA (Germán) : 1974, "El repertorio lingüístico de los sefarditas de Curaçao durante los siglos XVII y XVIII y el problema del origen del Papiamento", Romance Philology, 28, 1, pp. 1-16.

GRANT (Anthony P.) : 2008, "A constructivist approach to the early history of Papiamentu", in FARACLAS (Nicholas), SEVERING (Ronnie), WEIJER (Christa), eds. Linguistic studies on Papiamentu (Curaçao : Fundashon pa Planifikashon di Idioma), pp. 73-112.

GROENEBOER (Kees) : 1993, Weg tot het Westen (L̇eiden : KITLV Press).

GROENEBOER (Kees) : 1998, "Westerse koloniale taalpolitiek in Azië: het Nederlands, Portugees, Spaans, Engels en Frans in vergelijkend perspectief", Mededelingen der Koninklijke Nederlandse Akademie van Wetenschappen, 61, 2, pp. 1-28.

HARGREAVES (John D.) : 1965, "Assimilation in Eighteenth-Century Senegal", Journal of African History, 6, 2, pp. 177-184.

HARTOG (Johan) : 1968, Curaçao, from colonial dependence to autonomy (Aruba : De Wit).

HOLM (John A.) : 1988, Pidgins and Creoles (Cambridge: Cambridge University Press).

JACOBS (Bart) : 2011, "The origin and originality of passivization in Papiamentu", Journal of Portuguese Linguistics, 10, 2, pp. 31-56.

JACOBS (Bart) : 2012a, Origins of a Creole. The History of Papiamentu and It African Ties (Berlin: Walter de Gruyter).

JACOBS (Bart) : 2012b, "On the Dutch presence in 17th-century Senegambia and the emergence of Papiamentu" in GREEN (Tobias) and NAFAFE (Jose Lingna), eds Brokers of Change: Atlantic commerce and cultures in pre-colonial "Guinea of Cape Verde"' (Oxford: Oxford University Press), pp. 191-214.

JACOBS (Bart) : 2012c, "Embedding Papiamentu in the Mixed Language Debate", Journal of Historical Linguistics, 2, 1, pp. 52-82.

JACOBS (Bart) and van der WAL (Marijke) : to appear, "The discovery, nature, and implications of a Papiamentu text fragment from 1783", Journal of Pidgin and Creole Languages.

KESTER (Ellen-Petra) and FUN (Jennifer) : 2012, "Language use, language attitudell and identity among Aruban students in the Netherlands", in FARACLAs (Nicholas), SEVERING (Ronald), WEIJER (Christa) and ECHTELD (Elisabeth), eds. Multiplex Cultures and Citizenships (Curaçao: University of Curaçao / Fundashon pa Planifikashon di Idioma), pp. 231-248.

KLOOSTER (Wim) : 2009, "Manumission in an Entrepôt. The Case of Curaçao", in BRANA-SHUTE (Rosemary) and SPARKS (Randy J.), eds. Paths to Freedom. Manumission in the Atlantic World (Columbia: University of South Carolina Press), pp. 161-174.

KLOOSTER (Wim) and OOSTINDIE (Gert) : 2011, Curaçao in the Age of Revolutions, 1795-1800 (Leiden : KITLV Press).

KNIGHT (Marie-Hélène) : 1977, "Gorée au XVIII" siècle: L'appropriation du sol", Revue française d'Histoire d'Outre-Mer 64 (324) (pp 33-54).

KRAMER (Johannes) : 2004, Die iberoromanische Kreolsprache Papiamento (Hamburg: Helmut Buske).

KRAMER (Johannes) : 2008, "Die früheste Erwähnung und das früheste Wörterbuch des Papiamento", Romanistik in Geschichte und Gegenwart, 14, 1, pp. 99-114.

MARTINUS (Efraim Frank) : 1996, The Kiss of a Slave: Papiamentu's West-African Connections (Amsterdam : Universiteit van Amsterdam dissertation). 
MAURER (Philippe) : 1998, "El papiamentu de Curazao", in PERL (Matthias) and SCHWEGLER (Armin), eds. América Negra: panorámica actual de los estudios lingüísticos sobre variedades hispanas, portuguesas y criollas (Frankfurt am Main : Vervuert), pp. 139-217.

MAURER (Philippe) : 2011, The former Portuguese Creole of Batavia and Tugu (Indonesia) (London : Battlebridge)

MCWHORTER (John) : 2000, The Missing Spanish Creoles : Recovering The Birth of Plantation Contact Languages (Berkeley : University of California Press)

MINTZ (Sidney) : 1971, "The socio-historical background to pidginization and creolization", in HYMES (Dell), ed. Pidginization and Creolization of Languages (London : Cambridge University Press), pp. 481-498.

NIEWINDT (Martinus Joannes) : [1833]2002, Prefecto Apostulico di Curaçao na Cristian di su Mision (Bloemendaal : Libri Antilliani).

OOSTINDIE (Gert) : 1995, "Taal, geschiedenis en Antilliaanse identiteiten", in COOMANS (Henny E.), COOMANS-EUSTATIA (Maritza) and PRINS (Peter), eds. Caraïbische cadens. Liber amicorum opgedragen aan de Gevolmachtigde Minister van de Nederlandse Antillen Edsel A.V. [Papy] Jesurun, pp. 148-153.

OOSTINDIE (Gert) : 2008, "Migration and its legacies in the dutch colonial world", in OOSTINDIE (Gert), ed. Dutch colonialism, migration and cultural heritage (Leiden : KITLV Press), pp. 1-23.

PARKVALL (Mikael) : 1999, "On the Possibility of Afrogenesis in the Case of French Creoles", in RICKFORD (John R.) and ROMAINE (Suzanne), eds. Creole Genesis, Attitudes and Discourse (Amsterdam : Benjamins), pp. 187-214.

POSTMA (Johannes M.) : 1990, The Dutch in the Atlantic Slave Trade, 1660-1815 (Cambridge : Cambridge University Press).

PUTMAN (Jacobus Josephus) : 1849, Proeve eener Hollandsche spraakkunst, ten gebruike der algemeene armenschool (Curaçao : author's edition).

REINECKE (John E.) : 1937, Marginal Languages: A Sociological Survey of the Creole Languages and Trade Jargons (New Haven : Yale University Press)

RUPERT (Linda) : 2012, Creolization and Contraband : Curaçao in the Early Modern Atlantic World (Athens : University of Georgia Press).

SALOMON (H.P.) : 1982, "The Earliest Known Document in Papiamentu Contextually Reconsidered", Neophilologus, 66, 367-376.

SANCHEZ (Tara) : 2005, Constraints on structural borrowing in a multilingual contact situation (Philadelphia : University of Pennsylvania)

TURNER (Brian S.) : 2007, "Globalization, Religion and Empire in Asia", in BEYER (Peter) and BEAMAN (Lori), eds. Religion, Globalization and Culture (Leiden : Brill), pp. 145-166.

van der VELDEN (Bastiaan) : 2006, “'Salta Cacho, Salta Su Rabo'. Over de ontwikkeling van het gebruik van het Papiamentu als rechts- en bestuurstaal", UNA bundel (Curaçao: University of the Netherlands Antilles), pp. 163-198.

WALTMANS (Henk) : 2003, Een koninkrijk met de West (Oosterhout : author's edition)

van WIJK (Henri L.A.) : 1958, “Orígenes y evolución del Papiamentu”, Neophilologus, 42 , pp. $169-182$.

WOOD (Richard E.) : 1970, Papiamentu: Dutch Contributions (Bloomington : Indiana University)
ABSTRACT

Papiamentu has borrowed eonsiderably from Dutch with up to $30 \%$ of the vocabulary having Dutch roots. However, an important and hitherto insufficiently addressed historical- and socio-linguistic question is why Dutch itself did not creolize on Curaçao or otherwise become the principal language of the island's society at large, in spite of it being the principal European language on the island from start to present, and even though its presence there (from the 1630s onwards) predates that of Papiamentu (from the 1650s onwards). Most colonial languages in the Caribbean have had a vast. long lasting linguistic impact in their respective colonies, either 'producing' creoles (e.g. English on Jamaica or French on Haiti) or otherwise becoming the main vehicle of communication (e.g. Spanish on Cuba). Not, though, on Curaçao. On this island, the language of all social classes and ethnicities is Papiamentu, a creole with an Iberian lexical base. The present article explores this issue which, in the literature, is also known as the 'Curaçao Paradox'.

\section{RÉSUMÉ}

Le papiamentu a emprunté considérablement au néerlandais a tel point qu'environ $30 \%$ de son vocabulaire est d'origine néerlandaise. Cependant, une question historique et sociolinguistique qui a jusqu'à ce jour été relativement peu ou insuffisamment débatue est pourquoi le néerlandais lui-même ne s'est pas creolisé a Curaçao, ou au moins n'est pas devenu la langue principale de la société locale, quand bien même il a été la langue européenne principale sur l'île du début de son histoire coloniale jusqu'à aujourd'hui (dès les années 160) et sa présence est plus ancienne que celle du papiamentu (attesté dès les années 1650). La plupart des puissances coloniales européennes dans les Caraïbes eu un vaste et durable impact linguistique local, soit en produisant des créoles (e.g. l'anglais en Jamaïque ou le français à Haïti), ou autrement en devenant le principal biais de communication (e.g. l'espagnol à Cuba). Ce ne fut pas le cas à Curaçao. Sur cette île, la langue socialement et ethniquement la plus répandue est le papiamentu, un créole de base lexicale ibérienne. Le présent article tente de répondre à la question (le 'Paradoxe de Curaçao') pourquoi la langue coloniale, le néerlandais, n'a pas été approprié par la population locale, et pourquoi, au lieu de cela, le papiamentu a pu prendre forme, se diffuser et consolider sa position sur l'île.

\section{SAMENVATTING}

Op Aruba, Bonaire en Curaçao is het Papiaments, een op het Spaans en Portugees gebaseerde creooltaal, de taal van het grootste deel van de bevolking, ongeacht sociale klasse. Maarliefst 30\% van de Papiamentse woordenschat is weliswaar aan het Nederlands ontleend, tegelijk moet men zich echter de historische en sociolinguistische vraag stellen hoe het Papiaments zich zo sterk heeft kunnen manifesteren en waarom het Nederlands zelf op Curaçao geen sterkere impact heeft gehad. Het Nederlands was immers de taal van de kolonisatoren en werd op het eiland eerder gesproken (vanaf 1634) dan het Papiaments (vanaf de tweede helft van de 17e eeuw). Bij wijze van contrast: het Engels, Frans en Spaans hebben een veel dieper gaande, langdurigere impaet gehad in 'hun' respectievelijke kolonies in het Caribisch gebied. en hetzij in gecreoliseerde vorm (denk maar aan het Jamaican Creole op Jamaica, het Haitian Creole op Haiii) of in onveranderde vorm aan de locale bevolking overge- 